\title{
Living history fiction
}

\author{
Kim Wilson
}

During my research into historical fiction for children and young adult readers I came across a range of texts that relied on a living or lived experience of history to frame the historical story. These novels were similar to the time-slip narrative; however, not all examples used the traditional convention of time-slippage. I wanted to bundle these novels together - 'time-slip' novels included - as examples of 'living history' narratives because they appeared from the outset as a distinct literary form requiring particular reading strategies. These texts, which I will refer to as Living history novels, require readers to align uncritically with modern perception. Readers are persuasively invited to assume that the modern characters' perception of the past is authentic because it has been formed by a lived experience of history. In Living history novels, readers are positioned to perceive both the strengths and weaknesses of past and present times, ultimately reconciling the two in a present that faces chronologically forwards. Modern focalising characters in Living history fiction place modern perception in a superior relationship to that of the past.

This sub-genre of historical novels is distinctive in its strong and consistent modern character focalisation and point of view. The Living history novel creates a confluence of past and present, be it physically or psychically. Characters are variously conveyed from a generalised present, or past, to an explicit historical period or event. The Living history novel is distinctive in its intense character introversion, quest journey and self-discovery. The most important outcome of the living history experience is that characters learn something significant about themselves. Because the story is about the modern character's quest and self realisation, the past is consistently perceived from their point of view. Modern characters are transported in time and readers are only rarely invited to see the past from a past point of view.

\section{Defining the parameters of Living History Fiction}

As noted above, the category of Living history fiction includes more than the traditional time-slip narrative. The sub-genre can be divided into two broad categories: physical time travel and psychical cognitive connectivity (see Figure 1). 


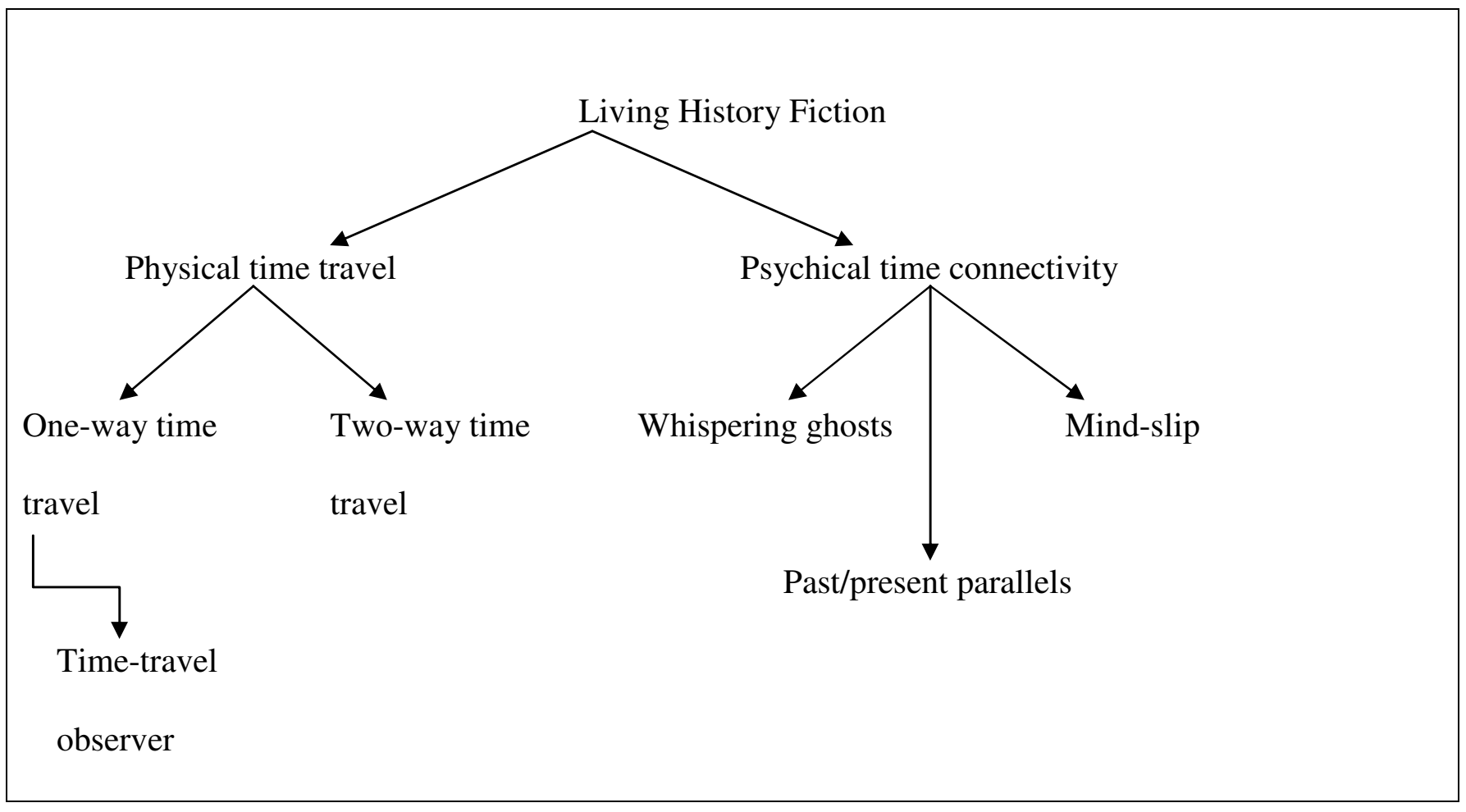

Figure 1: Categorising the sub-genre of Living history fiction

The physical time travel category comprises the popular 'one-way time travel' novels where modern character(s) are transported back in time usually (but not always) with one departure and one return journey. Past characters do not come into modern times. Some examples include: Susan Cooper King of Shadows (2000), Goldie Alexander Mavis Road Medley (1991), Jackie French Somewhere Around the Corner (2000), and Cory Daniels, Mystery at Devon House (1999). The 'two-way time travel' novel, for example Penelope Farmer's Charlotte Sometimes (1985, first published 1969), Ruth Park's Playing Beatie Bow (1982), and Hilary Bell's Mirror Mirror (1996), differ in so far as past characters come into the present as well as modern characters travelling back. There can also be multiple journeys back and forth as characters try to resolve some conflict pertinent to present and past. Finally, there is a small and unusual category of physical Living history fiction: the 'time-travel observer'. The 'timetravel observer' can by various capacities witness the past as it occurred but are unseen in that past, for example, in Kit Pearson's A Handful of Time (1987) and Jackie French's Daughter of the Regiment (1998).

The second arm of the sub-genre, psychical cognitive connectivity, includes 'mind-slips', 'whispering ghosts' and 'past/ present parallels'. Celia Rees' Sorceress (2002), Jackie French's Macbeth and Son (2006), and Welwyn Wilton Katz's Out of the Dark (1996) are examples of the 'mind-slip' novel where modern characters slip into the minds of historical characters to experience the past cognitively. While modern characters ostensibly see the past through historical eyes, their narrated eyewitness accounts are focalised by their modern self. Ghosts that whisper to the present such as found in Victor Kelleher's Baily's Bones (1988) and Nadia Wheatley's The House that was Eureka (2001) merge the past with the present by means of haunting, dreams and ghostly visitations. This type of novel forces modern characters to consider who they are, how the past relates to their present and how to move 
forward in their modern context. Finally, the 'past/ present parallel' is a multi-stranded narrative in terms of time, with overt correlations made between periods, creating a connection between past and present. Whilst there is no cross over of characters physically or cognitively Sue Gough's Wyrd (1993) and David Metzenthen's Boys of Blood and Bone (2003), for example, function in the same discoursal manner as the more traditional time-travel historical adventure.

Given the limitations of space in this essay, I will not attempt to address all categories of Living history fiction identified in Figure 1. Instead, I will take four examples to illustrate the particularities of this newly identified sub-genre of historical fiction. King of Shadows ('one-way time travel'), Daughter of the Regiment ('time-travel observer'), Wyrd ('past/present parallel') and The House that was Eureka ('whispering ghosts'), are alike in that the historical discourse is framed by either a physical or psychical experience of the past. Irrespective of whether the 'time-slip' convention is used, all four novels demonstrate the functionality of the sensory experience of the past to facilitate the quest for self discovery. All four novels demand readers align uncritically with the modern characters' perception of historical events. Each novel also closes off access to the past and celebrates the modern character's progression into the future by confirming his or her positive maturation by the conclusion of the narrative.

\section{Reading Living history fiction as a sensory experience}

The reading strategies I have identified for Living history fictions are clearly comparable with the visual interpretative strategies required at Living history museums. Living history sites use both historical artefacts, reconstructions and actors to provide the museum tourist with a sense of the past as tangible and living. Raphael Samuels argues in Theatres of Memory (1994) that 'if there is a unifying thread to these exercises in historical reconstruction it is the quest for immediacy, the search for a past which is palpably and visibly present' (p.175). In an article on living history and historic houses, Andrew Robertshaw (2007) comments that:

... on the living history site the visitor will find that there are no labels, no barriers, no proscribed route. The visitor is free to speak to or bypass the interpreters as they decide how to explore, how and when to interact. ... There will be sounds, smells ... People learn better when using as many senses as possible.

$$
\text { (2007, unpaginated) }
$$

Robertshaw points out three key features of the Living history museum experience: an authentic past is an unmediated past; acting out the past is performative; and sensory learning is more effective than reading a history book. There are clear parallels between the Living history museum and the Living history novel. Both modes of presenting history have particularised formulas and hence limitations to representing the past. Over the course of this paper, I will make reference to this complex of features identified by Robertshaw, beginning with the idea that a sensory approach to learning is more effective than the passive reading of documents and observation of artefacts.

Living history fiction positions readers to engage with the past as both intellectual inquiry and physical reality. Characters have seen, therefore they believe. In Cooper's King of Shadows, Nat Field is preparing to play Puck at the newly rebuilt Globe Theatre. Smelling and hearing the echo of past times Nat wakes up one morning in sixteenth century London, still an actor, and still in the role of Puck but training to appear in a production alongside William Shakespeare. In this novel the clearly directed reader subject position together with the pseudo eye witness reporting produce a historical fiction that 
is primarily concerned with the present. The novel frames history as a lived and living experience, consistently and persuasively leading readers to accept modern eye witness accounts of the past.

The authority of experiential learning is persuasively signalled in King of Shadows through Nat's ostensibly enlightened response to the twentieth century attempt at reconstructing Shakespearean theatre. Upon return to his twentieth century production of A Midsummer Night's Dream Nat looks at the costume and declares 'It's all wrong!' (2000, p.156). Having worn Puck's bona fide outfit consisting of a magnificently painted torso of leaves and tendrils accompanied by plain green hose, Nat is aghast at what he perceives as the ahistorical 'formal creamy brocade cloak, and ... puffy white pants and white legs' (p.156). Nat's perception is privileged by way of discoursal mocking of the costume designer's assumed authoritative but fallacious retort: 'Well, Nat, since neither of us was there when they did it [the original performance], I'm afraid you're just going to have to put up with what you've got.' (p.156)

There are issues here with the fact that Nat wants to have a historical costume when in fact Elizabethan costume was largely anachronistic in its time (a point also overlooked in the costume designer's retort). Either Cooper is unaware of this subtlety or chooses an unambiguous stance on Elizabethan costume in order to more clearly and convincingly communicate the ideological positioning of the narrative that seeing is believing. The past has been seen, felt and lived: the accuracy of Nat's eye witness - sensory - account of the past is favoured by the discourse, over and above its static counterpart. The distinct subject position offered by Living history fiction relies on the alignment of readers with modern characters.

While a historical novel creates an existing past, the Living history novel enhances the responsiveness of history by placing the present in direct dialogue with the past. Amy Elias (2005) explains: We strive to have a dialogue with history, perhaps because we perceive it to be not a thing or a sterile collection of written texts but rather a cacophony of voices of lived beings who preceded us in time. (2005, p.168) Living history fiction seduces by its capacity to engage modern readers in a supposed, but qualifiedly 'real' dialogue with history. When Nat converses with William Shakespeare, there is an intimacy with history: an intimacy absent in the inert textual traces of the past. Whilst an historian (or literary critic) can tell the reader that Shakespeare was sensitive to human frailties and diffidence, dialogue is far more persuasive:

[Shakespeare] put his arm over my shoulders and gave me a quick hug. And to my absolute horror, I fell apart. It was the sudden warmth and sympathy ... By accident, he'd released an emotional overload ...

In a little while he said quietly, '... What ails thee, Nat? What is it, this terrible buried sorrow? Dost miss thy parents?'

[After Nat explains the death of his mother and subsequent suicide of his father,] Shakespeare shifted a little. He said quietly, 'Nat Field. Thou hast a lot to bear.'... Shakespeare sat there with his hand on the back of my neck, rubbing it gently.

This interchange is an especially pertinent example of inviting readers to align with modern perception through the focalising character. The twentieth century understanding of suicide is very different from that of the sixteenth. Suicide in Shakespeare's time was a gross sin, resulting in eternal damnation for the offender. In the twentieth century, suicide is increasingly treated as the result of mental illness, the focus being on an affect of the mind rather than a flaw in the individual. Therefore, the impact of the 
act of suicide in a twentieth century interpretive model is on the family. Cooper's Shakespeare, as focalised by Nat, assumes a twentieth century disposition that empathises with Nat's burden rather than his father's damnation. It is an ahistorical interpretive position that the fictional Shakespeare has been placed into; nonetheless, it highlights the privileging of modern perception in Living history fiction and also the functionality of the living history experience to provide enlightenment in the present (rather than the past).

\section{The Other: the past is signifier for the present}

In King of Shadows, Cooper attempts to construct an unmediated encounter with the past by framing the historical experience as one of time-travelling. Robertshaw argues in his article on Living history museums that it is the appearance of an unmediated past that facilitates the sense of genuine encounter with history. He also refers to historical actors as 'interpreters'. This is the customary term used at Living history museums and has been adopted for the specific reason of drawing a distinction between 'acting' and 're-living' the past. The use of the term 'Historical Interpreter' is well-considered and deliberate: its intent is to conceal the performance mode of delivery and to suggest a more genuine, unadulterated historical experience. Because Nat's experience of living history is in real time, it has the appearance of the absence of tourist signage. ${ }^{1}$ This absence is part of its claim to authenticity. Further, the narration of descriptive contextual gobbets throughout the text attests to the narrative's factuality. By using time-travel to frame the historical encounter, the characters are positioned to be understood as gaining uncensored knowledge of the past. It is an 'authenticity as perfect simulation' (Handler \& Saxton 1988, p.242). Readers are positioned to put faith in the historicity of the story. Nonetheless, even though Nat is immersed in 'real time' and signifiers in the form of museum signage are absent, the past is mediated. Nat is in himself a signifier of otherness by recognising his difference from the past. This is most evident when he thinks:

I knew things they didn't. I could tell them to boil water before drinking it, to keep their food cold so it wouldn't spoil, to keep garbage out of the streets so that it didn't bring the rats, who spread disease.

$$
\text { (2000, p.140) }
$$

The twentieth century living experience of the past is created by characters' recognition that the past is different from their time, and also by episodes when historical characters point out those differences. Harry, Nat's sixteenth century friend, comments: 'Th'art an odd one, Nat Field. ... Tha knowst so much, and then sometimes tha knows nothing' (p.97). The queen, Elizabeth I, when meeting the players after the performance, likewise comments: 'Th' art a pretty sight, Puck. ... With a way of speaking that I cannot place ... And thou hast a particularity, a strangeness ...' (pp.134-135). By creating a time-slip Cooper is utilizing an astute framing device. Living History is evoked by the sheer otherness of modern perspectives. The past makes manifest Nat's time-specific sense of selfhood. Everywhere he looks, Nat recognizes that the past world is different from his own. Nat's observations are in fact the tourist signage signalling to readers that they are engaging in an 'authentic' experience of the past.

Jackie French's Daughter of the Regiment, an example of a 'time-travel observer' Living history novel, functions in a similar way to King of Shadows despite the fact that it does not rely on the more traditional 'time-slip' device for creating a sensory experience of the past. In this novel the modern character, Harry, has a view of the novel's setting through a peephole inside the family henhouse. He cannot pass into the other time nor talk to people there or see anything beyond what the peep hole allows. He is neither heard nor seen by historical characters and therefore effects no change in that 
historical location. Nonetheless, similarly to King of Shadows, the past becomes an instructive tool facilitating a humanistic discourse on ageless human concerns and frailties. The blurb on the back cover of Daughter of the Regiment asks, 'how can you help someone who lived more than 150 years ago'? In short, Harry can't.

Nonetheless, if the question was re-worded as: How can someone living 150 years ago help Harry?, then readers would indeed find a clear answer. What Harry observes by watching the historical Cissie at various stages of her life (from age six to about sixteen) is her resolute attachment and sense of belonging to the piece of land they both occupy (150 years apart). Cissie's grief at leaving the land and her later return teaches Harry something tangible about how one can be physically absent and yet still belong. Perceiving the nature of connectivity to one's origins gives Harry the courage to take up a place in boarding school: 'He would leave, like Cissie had. And, like Cissie, he'd come back,' (1998, p.127); 'She was happy here, thought Harry. It had been part of her, like it was part of him. No matter where he went, or what he did, this land would always in some way be his.' (p.128).

Harry's role as spectator ties the implications of his observations solely to the present. Positive character development by story's end represents how individuals can grow in strength and wisdom by attending to the past. By aligning readers with Harry's point of view, readers are positioned to accept both Harry's interpretation of the past together with the narrative commentary that presupposes his perception of the past is accurate.

Gough's Wyrd (1993) is a sophisticated example of the 'past/ present parallel' Living history novel. The modern narrative primarily follows the journey of Trace, a young homeless punk girl who joins streetkids in their march from Sydney to Surfers Paradise (vaguely reminiscent of the thirteenthcentury Children's Crusade). The secondary modern narrative strand follows the discovery of a medieval gem-encrusted book, believed to have belonged to Berengaria, the secret wife and queen of Richard the Lionheart. The third historical narrative strand is the story of the Saracen princess Berengaria, whose alleged marriage to Richard II solidified a peace treaty between the English Crusaders and the Saracen, Saladin the Great. As in the 'one-way time travel' and 'time-travel observer' categories of Living history novels, the past has something to reveal - in and of itself and, also, for the benefit of the present. Trace's journey brings her into the second narrative strand, where in the company of three diverse strangers, her sense of selfhood begins to emerge:

The months that Trace had spent at Mandala were the best of her life. It was as if she were a stunted plant that had suddenly been transplanted and given the right kind of fertiliser. She flourished ... It had been harder to change the inside but it was happening. Berengaria's writings had helped.

$$
\text { (1993, p.111) }
$$

Berengaria's tale, knowledge and wisdom were ultimately preserved and 'now belonged to every woman' (p.122). The typical and overt signposting of the purpose of the historical narrative is clear in the emphasised section of the extract cited above. The story culminates with birds singing and the sun shining: Trace 'did not look back' (p.123).

The 'time-travel observer' and 'past/present parallel' Living history novels, like the 'one-way time travel' King of Shadows, focus very clearly on the present. Access to the past points modern characters firmly to their future. In this way the story of personal growth has been clearly emplotted in the historical discourse of the text. Living history fiction draws (I suspect unknowingly) on the conventions of Living history museums. Modern characters present a seemingly textually unmediated experience of 
the past. Time-travelling and time-observing characters overtly frame the past within a modern perception.

\section{Otherness: narrative closure}

Jacques Le Goff (1992) argues that 'the distinction between past and present is an essential component of the concept of time. It is therefore fundamental to both historical consciousness and historical knowledge' (p.1). Signification allows the past to exist in the present, and the present day requires the past to be othered so as to signify its modernity. As such, the recognition of otherness is comforting. There is a two-fold purpose in the convergence and othering of past and present in Living history fiction: in the first instance, the unresolved issues from the past must be satisfactorily worked through, and in the second, modern characters must learn something from the encounter so that they can continue moving forward. The theme of returning to the present or resolving some conflict from past times is the pertinent aspect for narrative closure. Closure of the narrative provides the fiction with coherence. In their study of the idea of authenticity in Living history Handler and Saxton (1988) argue that 'an outstanding feature of the historical worlds created by living history is that they have narrative coherence; that is, they are emplotted or constituted as stories (p.243).

Similarly, in the Living history novel, discerning the past as Other keeps it contained within its 'pastness'. The pressure to make the past other manifests itself in a compulsion for closure. In the physical time-travel novel the frame is a departure from and return to the present, which then frames the past. While narrative closure can be, and generally is, a feature of historical fiction, it is an obligatory feature of the Living history novel.

Narrative coherence is important to the time-travelling lived experience of Nat in King of Shadows. For Nat the import of the time-slip is signalled by his burgeoning capacity to overcome the grief from his younger years. Nat felt 'rescued [by Shakespeare] from the pit [he] was in' (2000, p.166). And now, when he cried for his dead father his eyes filled with tears, but, 'they were good tears, somehow, better than the dry pain that [he had] had for so long' (p.174). Nat's experience of sixteenth-century London provided him with an opportunity to engage in intersubjective relationships with signifying others. The discourse of King of Shadows concludes with a past reconciled and concluded, and with the protagonist turning away from the past and towards the prospect of a fulfilling future. What the reader becomes aware of nearing the end of the tale is that the manner in which Nat reports on the past does not change. The foreignness, the sheer otherness of the past is something he 'could never understand' (p.101). Nat is gaining a particularised form of knowledge: an empathetic and sensory insight into his self rather than the past. In King of Shadows readers are positioned to understand that the effect of the living history experience is to provide characters with a sense of selfhood.

Wheatley's The House that was Eureka (2001) is an example of the 'whispering ghosts' sub-category of Living history fiction. Although there is no physical 'time-travel' or 'observation', the novel functions in the same manner as King of Shadows and Daughter of the Regiment. In The House that was Eureka the past is merged with the present by means of dreams and enduring familial connections. The narrative shifts between the present time and the past to give form to the dreams and to make sense of the connections between time periods. The necessity to close off the past in The House that was Eureka is urgent. Entwining sentient traces of the past within modern consciousness is potentially maddening for the individual who is cognitively connected to the past. The encroachment of spectres from history signifies an untamed past. In this novel Wheatley weaves a disturbing and in some ways unresolved event from the 1930s into the present. Mrs Weston, Noel's Aunty and the fiendish Landlady of the Depression era, is trapped in a time warp. She refuses to see the past as other by continually 
engaging with the past in a manner that keeps it living concurrently with the present. She ensnares herself with the maddening desire to re-write the past, repeatedly chanting 'If I write it differently, it happened differently' (p.297). Her powerlessness to change the past together with her determination to keep the past perpetually present results in an effacement of Mrs Weston's identity. She cannot distinguish between her 1930s and 1990s persona:

Her memory had been playing tricks on her lately... And now it was her memory that seemed to be paying her back for all that tricksiness of the past.

The past. When was that?

She could have sworn there was that battle tonight ... Or was that last week? Or even years ago?

(2001, p.373)

An untamed past has no closure. Mrs Weston's sense of selfhood is dislocated because she refuses to acknowledge the otherness of the past. Failure to distinguish the past as other, results in a form of insanity.

The merging of past with present is also dangerous for the young modern characters of this novel. Evie, haunted by dreams of the 1930's Lizzie, feels her sense of individuality slipping away. Becoming significantly thinner and with her hair dyed black, Evie begins to look like Lizzie. The internalisation of the past into the present is clearly articulated when Evie dreams of Lizzie, 'Oh, it's you, she thinks as if the face she has just seen is someone she has known from way back - primary school perhaps. (Or from the mirror!)' (p.214). Similarly, Noel's sense of identity is also beleaguered by the past. He perpetually dreams and acts out the 1930s torment of Nobby, his uncle. The convergence of the past with the present in the present is dangerous for those in whom the confluence is situated. The discourse indicates that it will ultimately lead to insanity.

Bygone restraints that are perpetually operative affect a loss of identity through an inability to define the self in relation to the absence of the other. Both Evie and Noel separately articulate that events must be played out in order to conclude the historical tale, to separate the past from the present, and to reestablish linear time. For Noel's nightmare to end the past must be closed off - it must become other: 'Acting/act, Noel thought. He'd been thinking for a while that if he could somehow act out his nightmare, all the way through to the end - then maybe it would be over' (p.272). And this indeed is how the nightmare is tamed. Historical re-enactment of the past facilitates reconciliation between Nobby and his mother (Mrs Weston), it allows Lizzie to tell Nobby (via Evie) that she loved him, and it opens up a future for Evie and Noel where they will function as independent, engaged subjects.

Closure of the narrative in The House that was Eureka signifies character maturation. The import of the living history experience for both Noel and Evie is manifest in their readiness to engage with the present and assert their sense of ' I am' and 'I am becoming' in a dialogic relation to others' (see Wilson 2001, p. 25). In the first instance Evie dissociates herself from the past: 'A long time ago? Evie tested what she had just said. Yes, it felt like that now' (p.383). She recognises the empty and solipsistic state she had once inhabited and perceives that it is 'better to be alive and flying' (p.394). Noel similarly decides that rather than withdrawing into his shell, it is far better for him to engage with the world. He is overcome by a surge of confidence: 'Matt and others like him [childhood bullies] weren't going to get him down in the future' (p.401); 'He would never have thought ... that he could have reached out and taken Evie's hand - just like this!' (p.403). By disavowing solipsism and engaging in dialogic relationships with others Evie and Noel are both forging a sense of selfhood. Ghosts have been laid to rest, old conflicts resolved, characters feel happy 'for the first time in so many 
years' (p.403) and linear time is restored. The past has been contained within its 'pastness' and the narrative closes with the characters sensing that they are facing forwards - looking at the beginning of a new story.

Narrative coherence in Living history fiction has salience at both story and discoursal level. At story level, closure is indicative of the protagonist's maturation. It is important thematically for this type of novel to conclude as the characters sense they are facing forwards - looking at the beginning of a new story. At discoursal level, when linear time is restored the past has been successfully othered and hence contained within its 'pastness'. In this way, the Living history novel both performs its distinctive literary form and requires readers to read strategically. While Living history fiction sets out to immerse readers in the sensation of the past, this literary form is always, paradoxically, engaged with the present. Readers' attention is constantly directed to use the past to ruminate upon the present.

\section{Conclusion}

What emerges from examination of the Living history novel is the functionality of lived experience, in the first instance, to position readers to understand the past from a particular contextual basis and, in the second, to use the past as both signifier and signified in the discernment of modernity. Living history fiction is undoubtedly creating a past to excite the senses; however, the senses are not so much excited about the past, but incited to engage with the present. The past, in many ways is a function of the narrative: the quest for modern selfhood emplotted in the historical discourse of the living experience.

\section{Endnote}

1. See Jonathan Culler's discussion of signposting historical sites in Framing the Sign (1988).

\section{References}

Alexander, Goldie (1991) Mavis Road Medley. Sydney, Margaret Hamilton.

Bell, Hilary (1996) Mirror Mirror. Sydney, Hodder Headline Australia.

Cooper, Susan (2000) King of Shadows. London, Puffin Books.

Culler, Jonathan (1988) Framing the Sign: Criticism and its Institutions. Oxford, Basil Blackwell.

Daniels, Cory (1999) Mystery at Devon House. Melbourne, Lothian Books.

Elias, Amy J. (2005) 'Metahistorical Romance, the Historical Sublime and Dialogic History', Rethinking History 9, 2/3, 159-172.
Farmer, Penelope (1985) Charlotte Sometimes. London, The Bodley Head [1969]. French, Jackie (1998) Daughter of the Regiment. Sydney, Angus and Robertson.

French, Jackie (2006) Macbeth and Son. Sydney, Angus and Robertson.

French, Jackie (2000) Somewhere Around the Corner. Sydney, Angus and Robertson.

Gough, Sue (1993) Wyrd. St Lucia, University of Queensland Press.

Handler, Richard \& Saxton, William (1988) 'Dyssimulation: Reflexivity, Narrative, \& the quest for Authenticity in 'Living History", Cultural Anthropology 3, 3, 242-260. 
Katz, Welwyn Wilton (1996) Out of the Dark. New York, Margaret K. McElderry.

Kelleher, Victor (1988) Baily’s Bones.

Ringwood, Vic, Penguin.

Le Goff, Jacques (1992) History and Memory. Trans. Steven Rendell \& Elizabeth Claman. New York, Columbia University Press [1977].

Metzenthen, David (2003) Boys of Blood and Bone. Ringwood, Vic, Penguin.

Park, Ruth (1982) Playing Beatie Bow. Ringwood, Vic, Penguin.

Pearson, Kit (1987) A Handful of Time. Toronto, Penguin.
Rees, Celia (2002) Sorceress. London, Bloomsbury.

Robertshaw, Andrew. (Accessed 03/06/2007). "“A dry shell of the past": Living history and the interpretation of historic houses', Association for Heritage Interpretation: History Re-Enactment Workshop. http://www.heritageinterpretation.org.uk/journals/j2c-shell.html

Samuel, Raphael (1994) Theatres of Memory: Vol 1: Past and Present in Contemporary Culture. London and New York, Verso.

Wheatley, Nadia (2001) The House that was Eureka. Ringwood, Vic, Penguin.

Wilson, Kim (2001) 'Abjection in Contemporary Australian Young Adult Fiction', Papers: Explorations into Children's Literature 11,3, 24-31.

\section{Biographical note}

Kim Wilson has recently completed a Ph.D. in English, specializing in children's literature, at Macquarie University (Australia). Her research examined the ideological framing of children's historical fiction that has been published over the last thirty to forty years. She has published in Journal of International Children's Research, Children's Literature Association Quarterly, and Papers. 